\title{
A rare breast tumor: primary neuroendocrine carcinoma
}

\author{
Hüseyin Pülat ${ }^{1}$, Mehmet Zafer Sabuncuoğlu ${ }^{2}$, Oktay Karaköse ${ }^{1}$, Mehmet Fatih Benzin², Hasan Erol Eroğlu ${ }^{1}$, Kemal Kürşat Bozkurt ${ }^{3}$ \\ ${ }^{1}$ Division of Surgical Oncology, Süleyman Demirel University School of Medicine, Isparta, Turkey \\ 2 Department of General Surgery, Süleyman Demirel University School of Medicine, Isparta, Turkey \\ ${ }^{3}$ Department of Pathology, Süleyman Demirel University School of Medicine, Isparta, Turkey
}

* This study was presented at the $19^{\text {th }}$ National Congress of Surgery, 16-20 April 2014, Antalya, Turkey.

\begin{abstract}
Breast cancer is the most frequently seen cancer in females but primary neuroendocrine carcinoma of the breast, which was defined as a separate entity in the 2003 World Health Organisation tumour classification, is seen extremely rarely. This entity, which is still not well-defined and has not been well-researched, demonstrates a more aggressive course than invasive ductal carcinoma. As metastatic breast neuroendocrine tumours are more widespread and the treatment strategy is different, preoperative differential diagnosis is important. The basic diagnostic method is pathological examination. If a neuroendocrine pattern is determined in microscopy, then immunohistochemical study of neuroendocrine markers should be made. It is necessary to be vigilant in terms of synchronous tumours and metachronous tumours which may develop in the postoperative period as the incidence of synchronous and metachronous cancers in patients with neuroendocrine tumours is higher compared to the general population. The case presented here is of a 73-year old patient who presented with complaints of a breast lump, which was thought to be invasive breast cancer, and as a result of the operation with pathological and immunohistochemical examination, primary neuroendocrine carcinoma of the breast was determined. With more advanced evaluations, no synchronous or metachronous tumours were determined.
\end{abstract}

Keywords: Breast cancer, neuroendocrine carcinoma, treatment, surgery

Cite this article as: Pülat $H$, Sabuncuoğlu MZ, Karaköse $\mathrm{O}$, Benzin MF, Eroğlu HE, Bozkurt KK. A rare breast tumor: primary neuroendocrin carcinoma. Turk J Surg 2019; 35 (3) 236-240.

\section{Corresponding Author}

Oktay Karaköse

E-mail: oktaykarakose@gmail.com

Received: 11.02 .2015

Accepted: 10.06 .2015

Available Online Date: 03.01.2018

O Copyright 2019 by Turkish Surgical Society Available online at www.turkjsurg.com

DOI: 10.5578/turkjsurg.3109

\section{INTRODUCTION}

Neuroendocrine cancers of the breast refer to a heterogenous group of tumours which comprise less than $1 \%$ of all breast tumours (1). They show similar morphological features to neuroendocrine neoplasmas of the intestine and lungs. For diagnosis of a neuroendocrine tumour, at least $50 \%$ of the tumour cell must express one or more of the neuroendocrine markers (neuron specific enolase, chromogranin, synaptophysin) $(2,3)$. These tumours, which are more often seen in elderly patients, have a high tendency to local and distant recurrence and show an aggressive course with low general survival rates $(2,4)$. Synchronous tumours are an almost inseparable part of neuroendocrine breast tumours (5). The treatment for a primary neuroendocrine tumour of the breast is firstly surgery then, depending on the status, hormonotherapy, chemotherapy or radiotherapy can be added (6).

\section{CASE REPORT}

A 73-year old female presented at the clinic with complaints of pain and swelling, redness of the skin and bruising in the right breast. The patient had noticed the swelling in the breast one month previously, and the redness and brusing of the skin had occurred in the last week. The patient was the mother of two children, each of whom she had breast-fed for approximately one year. She had never used any oral contraceptive agent or hormone replacement therapy. She had passed through menopause 30 years previously. On physical examination, a hard immobile mass, $4 \times 2 \mathrm{~cm}$ in size, was palpated in the right breast $2 \mathrm{~cm}$ from the areola at 11 o'clock. There was an area of redness and ecchymosis of pink-purple colour on the skin of the breast over the mass. In the right axillary region, lymphadenopathy was palpated. Tumour markers were negative. 
On ultrasonography (USG) of the right breast, malignant lymph nodes were determined in the right axilla and a mass lesion, $31 \mathrm{x}$ $23 \mathrm{~mm}$ in size, located $2 \mathrm{~cm}$ from the areola at 11 o'clock, in a hypoechoic pattern with no evident vascularity on the colour Doppler USG examination, with irregular borders which could not be clearly differentiated from the pectoral muscle with no posterior acoustic shadow observed. On mammography, a macrolobular mass lesion was observed $3 \times 2 \mathrm{~cm}$ in size in the superior-external quadrant of the right breast (Figure 1).

Tru-cut biopsy was applied to the mass lesion under USG guidance. In histopathological examination, a tumour was observed showing infiltration in the form of large solid islands in the fibrous stroma. In the centre of these solid islands, scattered rosette-like structures were seen and occasionally cells which resembled signet rings. In immunohistochemical staining with GCDFP15, CK7 and NSE, there was cytoplasmic positive reactivity in a section of the neoplastic cells, 95\% estrogen receptor (ER) positive reactivity, $85 \%$ progesterone receptor (PR) positive reactivity and CK20 and C-erb b2 negative reactivity. In p53 staining, myoepithelial layer was not observed. With these findings, invasive ductal carcinoma

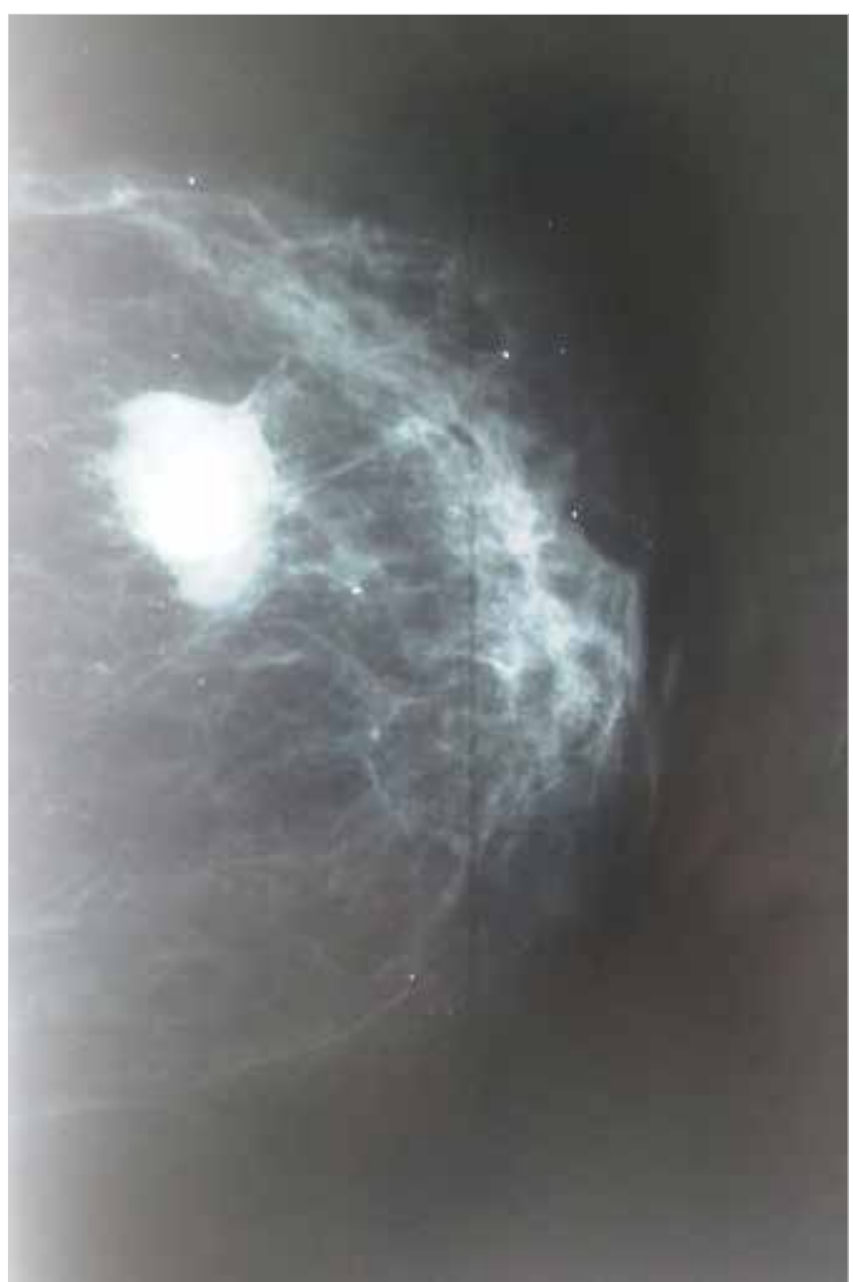

Figure 1. Mass appearance on mammography.

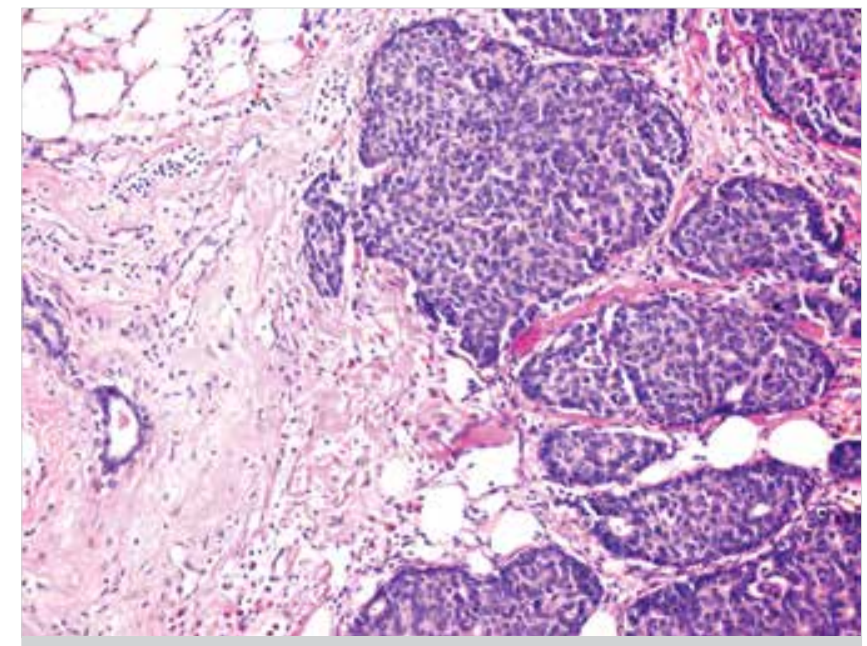

Figure 2. Invasive ductal carcinoma of the breast with neuroendocrine differentiation (H\&E x200)

displaying neuroendocrine characteristics, was reported as histological Grade 1. No other primary tumours were determined outside the breast from the cranial, neck, thoracic and abdominal computed tomography (CT) examination and gastrointestinal endoscopy, so a modified radical mastectomy (MRM) was applied to the patient. Pathology examination results of the biopsy material were histological Grade 3 according to the World Health Organisation 2010 classification. Tubule formation was graded as 3, nuclear pleomorphism as 2 and mitosis as 3 (under 12/10 magnification). The invasive tumour was $4 \mathrm{~cm}$ in diameter (pT2).

In the examination of the axillary dissection material, 14 reactive lymph nodes were determined (pNo). In the immunohistochemical examination with neuron specific enolase (NSE), cytoplasmic positive reactivity was determined in most of the cells. The Ki 67 proliferation index was below $5 \%$. With these findings, the patient was evaluated with stage 2A (pT2NOMO) of luminal A type invasive ductal carcinoma showing neuroendocrine differentiation (Figure 2 and 3). As no synchronous tumour was determined, it was accepted as a primary solid neuroendocrine carcinoma of the breast. Anastrozol, (1 mg/day Arimidex) as an aromatase inhibitor, was started and with no recommendation for adjuvant chemotherapy or radiotherapy, the patient was followed up for four years with no problems.

\section{DISCUSSION}

Neuroendocrine tumours, which are found all over the body, originate from submucosal neuroendocrine cells. The majority of these cells are localised in the gastrointestinal and bronchopulmonary system. Primary neuroendocrine carcinoma of the breast comprise $1 \%$ of all neuroendocrine carcinomas (7) and less than $0.1 \%$ of all breast tumours (1).

Histogenesis of the tumour has not been fully clarified as yet. Very few researchers have hypothesised that rather than the carcinoma 

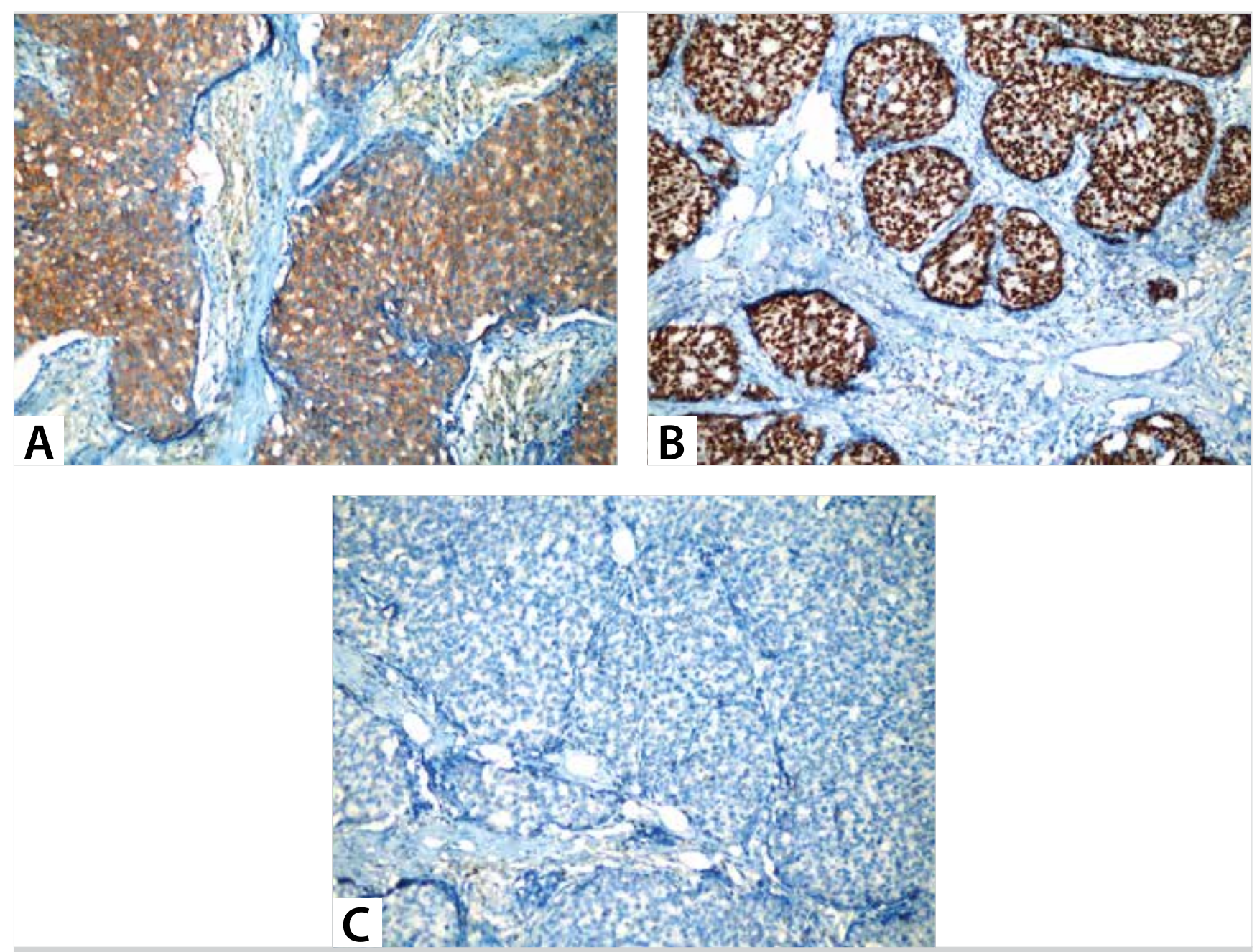

Figure 3. Immunohistochemical positive immunoreactivity for NSE $(A, \times 200)$ and $E R(B, \times 200)$ and negative immunoreactivity for HER-2 (C, x200).

originating from endocrine cells which are present in the breast, it shows endocrine differentiation of the breast. The majority; however, consider that they have originated from the differentiation of the neuroendocrine carcinoma phenotype of the multipotent stem cells (8).

Neuroendocrine cells can be determined in a random way in 10$50 \%$ of the breast tumours (9). This focal neuroendocrine differentiation pattern is found in invasive ductal, mucinous or signet ring cell carcinoma (10). According to the World Health Organisation 2003 tumour classification, to be able to make a diagnosis of a neuroendocrine breast tumour, one of the neuroendocrine markers such as neuron specific enolase, chromogranin-A, synaptophysin or CD56, must be revealed immunohistochemically in more than $50 \%$ of the tumour cells. Primary neuroendocrine carcinoma of the breast includes solid neuroendocrine carcinoma, atypical carcinoid tumour, small cell tumour/oat cell carcinoma and large cell carcinoma (11). The case prresented here was the solid type.
Studies have been carried out related to molecular subtyping. In a study by Weigelt et al. (12), five of six cases were found to be luminal A type and one case was luminal B type. In a single case report by Watrowski et al. (13), the case was luminal B type and molecular classification was reported to be helpful in the treatment strategy. The case presented here was luminal A type.

Compared with the general population, there is a high incidence of synchronous and metachronous cancers in patients with neuroendocrine tumours (14). In a study by Lopez-Bonet et al. (5), a second tumour has been found in 5 of 12 cases. In the case presented here, no secondary tumour was determined and it was accepted as a primary neuroendocrine carcinoma of the breast.

In the literature, the majority of these cases are 60-70 years of age. There is no specific clinical or radiological characteristic different from other breast malignancies (11). According to Samli et al. (15), the complaints related to this disease are breast cellulitis, mastitis, abscess and inflammation of the breast. Tumours are not seen bilaterally and are more often located in the left breast. In 
the case presented here, the patient was 73 years of age and had complaints of redness and bruising on the skin of the breast. The tumour was determined as a hard, immobile mass in the right breast.

Neuroendocrine carcinoma displays a more aggressive course than invasive ductal carcinoma (4,8). Five-year local and distant recurrence rates have been found to be $15 \%$ and 34\%, respectively (4). Mucinous differentiation and ER/PR positivity are good prognostic factors (8). The most common sites of metastasis are the bones and liver (4).

The surgical treatment for primary neuroendocrine cancer of the breast ranges from lumpectomy to MRM (6). In cases of large, multifocal or retro-areolar tumours, MRM is preferred (4). If there is $\geq 10 \%$ expression of Ki67 protein, which is used to define the aggressiveness and proliferation activity of the tumour, then adjuvant chemotherapy may be given. Hormonotherapy with tamoxifen or aromatase inhibitors is applied to patients with ER and/or PR positivity. Radiotherapy is used for patients who undergoing breast-conserving surgery and/or patients who have 3 or more axillary lymph node metastases (5). In the current case, MRM was applied as a surgical procedure. Ki67 expression was below 10\% and oestrogen and progesterone receptors were positive. Therefore, as the patient was postmenopausal, aromatase inhibitor was administered without adjuvant chemotherapy.

\section{CONCLUSION}

When a diagnosis is made of a primary neuroendocrine cancer of the breast, it is necessary to make an evaluation in respect of synchronous and metachronous tumours to be able to adapt the prognosis and treatment strategy for the patient.

Informed Consent: Written informed consent was obtained from patients who participated in this study.

Peer-review: Externally peer-reviewed.

Author Contributions: Concept - H.P., M.Z.S., O.K.; Design - M.F.B., H.E.E. K.K.B.; Supervision - H.P., M.F.B., H.E.E.; Materials - M.Z.S., O.K., K.K.B.; Analysis and/or Interpretation - H.P., M.Z.S., H.E.E.; Literature Search - O.K., K.K.B., H.P.; Writing Manuscript - H.P., O.K.; Critical Reviews - H.E.E., M.Z.S., K.K.B.

Conflict of Interest: No conflict of interest was declared by the authors.

Financial Disclosure: The authors declared that this study has received no financial support.

\section{REFERENCES}

1. Rovera F, Masciocchi P, Coglitore A, La Rosa S, Dionigi G, Marelli M, et al. Neuroendocrine carcinomas of the breast. Int J Surg 2008; 6: 113-5. [CrossRef]

2. Ogawa H, Nishio A, Satake H, Naganawa S, Imai T, Sawaki M, et al. Neuroendocrine tumor in the breast. Radiat Med 2008; 26: 28-32. [CrossRef]

3. Gündüz $M$, Işcan $Y$, Erbil $Y$, Müslümanoğlu M. Neuroendocrine differentiated breast carcinoma: A case report. J Breast Health 2009; 5: 225-7.

4. Wei $B$, Ding $T$, Xing $Y$, Wei $W$, Tian $Z$, Tang $F$, et al. Invasive neuroendocrine carcinoma of the breast: a distinctive subtype of aggressive mammary carcinoma. Cancer 2010; 116: 4463-73. [CrossRef]

5. López-Bonet E, Alonso-Ruano M, Barraza G, Vazquez-Martin A, Bernadó L, Menendez JA. Solid neuroendocrine breast carcinomas: incidence, clinico-pathological features and immunohistochemical profiling. Oncol Rep 2008; 20: 1369-74. [CrossRef]

6. Bozkurt MA, Kocataş A, Özkan Y, Kalaycı MU, Alış H. A rare entity of breast cancer: primary neuroendocrin carcinoma. J Breast Health 2014; 10: 242-4. [CrossRef]

7. Upalakalin JN, Collins LC, Tawa N, Parangi S. Carcinoid tumors in the breast. Am J Surg 2006; 191: 799-805. [CrossRef]

8. Stita W, Trabelsi A, Gharbi O, Mokni M, Korbi S. Primary solid neuroendocrine carcinoma of the breast. Can J Surg 2009; 52:289-90.

9. Zekioglu O, Erhan Y, Ciris M, Bayramoglu H: Neuro-endocrine differentiated carcinomas of the breast: a distinct entity. Breast 2003; 12: 251-7. [CrossRef]

10. Sapino A, Righi L, Cassoni P, Papotti M, Pietribiasi F, Bussolati G. Expression of the neuroendocrine phenotype in carcinomas of the breast. Semin Diagn Pathol 2000; 17: 127-37.

11. Tavassoli FA, Devilee P. Tumors of the breast: neuroendocrine tumors. In: Tavassoli FA, Devilee P (eds). World Health Organization Classification of the Tumors: Pathology and Genetics of Tumours of the Breast and Female Genital Organs. Lyon: IARC Press, 2003: 32-4.

12. Weigelt B, Geyer FC, Horlings HM, Kreike B, Halfwerk H, Reis-Filho JS. Mucinous and neuroendocrine breast carcinomas are transcriptionally distinct from invasive ductal carcinomas of no special type. Mod Pathol 2009; 22: 1401-14. [CrossRef]

13. Watrowski R, Jäger C, Mattern D, Horst C. Neuroendocrine carcinoma of the breast: Diagnostic and clinical implications. Anticancer Res 2012; 32: 5079-82.

14. Prommegger R, Ensinger C, Steiner P, Sauper T, Profanter C, Margreiter $R$. Neuroendocrine tumors and second primary malignancy, a relationship with clinical impact? Anticancer Res 2004; 24: 1049-51.

15. Samli B, Celik S, Evrensel T, Orhan B, Tasdelen I. Primary neuroendocrine small cell carcinoma of the breast. Arch Pathol Lab Med 2000; 124:296-8. 


\section{OLGU SUNUMU-ÖZET}

Turk J Surg 2019; 35 (3): 236-240

\section{Nadir bir meme tümörü: primer nöroendokrin karsinom}

Hüseyin Pülat ${ }^{1}$, Mehmet Zafer Sabuncuoğlu ${ }^{2}$, Oktay Karaköse ${ }^{1}$, Mehmet Fatih Benzin ${ }^{2}$, Hasan Erol Eroğlu ${ }^{1}$, Kemal Kürşat Bozkurt ${ }^{3}$

1 Süleyman Demirel Üniversitesi Tıp Fakültesi, Cerrahi Onkoloji Bilim Dalı, Isparta, Türkiye

${ }^{2}$ Süleyman Demirel Üniversitesi Tıp Fakültesi, Genel Cerrahi Anabilim Dalı, Isparta, Türkiye

${ }^{3}$ Süleyman Demirel Üniversitesi Tıp Fakültesi, Patoloji Anabilim Dalı, Isparta, Türkiye

\section{ÖZET}

Meme kanseri, kadınlarda en sık görülen kanser olmasına rağmen, Dünya Sağlık Örgütü'nün 2003'teki tümör sınıflandırmasında farklı bir antite olarak tanımlanan memenin primer nöroendokrin karsinomu; oldukça nadir görülür. Henüz iyi tanınmamış ve üzerine çalışılmamış olan bu antite, invaziv duktal karsinomadan daha agresif bir seyir göstermektedir. Metastatik meme nöroendokrin tümörleri, daha yaygın olduğundan ve tedavi stratejileri farklı olduğundan preoperatif ayırıcı tanı önemlidir. Temel tanı yöntemi patolojik incelemedir. Mikroskopide nöroendokrin patern saptanırsa immünohistokimyasal olarak nöroendokrin markerlar çalışılmalıdır. Senkron tümörler ve postoperatif dönemde gelişebilecek metakron tümörler yönünden uyanık olunmalıdır. Çünkü genel nüfus ile karşılaştırıldığında nöroendokrin tümörlü hastalarda senkron ve metakron kanserlerin insidansı daha yüksektir. Kliniğimize memede kitle şikayeti ile başvuran, invaziv meme kanseri düşünülerek opere edilen ve patolojik inceleme ve immünohistokimyasal yöntemler sonucunda memenin primer nöroendokrin karsinomu saptanan 73 yaşındaki bir hastayı sunuyoruz. Daha ileri değerlendirmeler ile herhangi bir senkron veya metakron tümör tespit edilmemiştir.

Anahtar Kelimeler: Meme kanseri, nöroendokrin karsinom, tedavi, cerrahi

Doi: 10.5578/turkjsurg.3109 